American University Washington College of Law

Digital Commons @ American University Washington College of

Law

Articles in Law Reviews \& Other Academic

Journals

Scholarship \& Research

2007

\title{
Molecular Federalism and the Structures of Private Lawmaking
}

David Snyder

American University Washington College of Law, dsnyder@wcl.american.edu

Follow this and additional works at: https://digitalcommons.wcl.american.edu/facsch_lawrev

Part of the Comparative and Foreign Law Commons, and the Jurisdiction Commons

\section{Recommended Citation}

Snyder, David, "Molecular Federalism and the Structures of Private Lawmaking" (2007). Articles in Law Reviews \& Other Academic Journals. 1412.

https://digitalcommons.wcl.american.edu/facsch_lawrev/1412

This Article is brought to you for free and open access by the Scholarship \& Research at Digital Commons @ American University Washington College of Law. It has been accepted for inclusion in Articles in Law Reviews \& Other Academic Journals by an authorized administrator of Digital Commons @ American University Washington College of Law. For more information, please contact kclay@wcl.american.edu. 


\title{
Molecular Federalism and the Structures of Private Lawmaking
}

\author{
David V. SNyder ${ }^{*}$
}

\section{Abstract}

This article explores "molecular federalism." Private lawmakers_ranging from familiar organizations like the American Law Institute and the New York Stock Exchange to less well known ones, like the International Chamber of Commerce and associations of banks-are here envisioned as part of a federalist scheme that operates at a "molecular" level rather than at the level of the state. The function and legitimacy of private lawmakers, and the strengths and weaknesses of private lawmaking, are assessed under the rubric of federalism. The article takes up both horizontal and vertical aspects of molecular federalism, considering the possibilities of competitive private lawmaking and the potential for (and limits of) governmental control. The article accounts for the extraterritoriality of private lawmaking and considers how private legislation may escape some of the vertical checks and balances associated with state-based federalism, not only through extraterritoriality, but also through some surprising shifts in the federalist hierarchy. The paper also explores how one legal regime can become dominant, while other contexts may suffer legal fragmentation. The paper attempts to place its analysis within the context of some prominent U.S. theorists of federalism, including Herbert Wechsler and Justice Brennan, and contemporary European theorists, such as Gunther Teubner. The conclusion is that molecular federalism, like its statebased counterpart, produces mixed results, and often in a way that accentuates both the

- Professor of Law, Washington College of Law, American University, Washington, D.C. This paper was prepared for presentation at the Second International Workshop in Comparative Research in Law and Political Economy, Osgoode Hall Law School, Toronto, 9 November 2006, and I would like to extend my sincere thanks to Professor Dr. Peer Zumbansen for the invitation and to the other workshop participants for their comments. I am also grateful to workshop participants at American University for their comments and to Janette $M$. Hays for research assistance. Further comments and reactions are quite welcome at dsnyder@wcl.american.edu. All remaining errors are my own. 
strengths and the weaknesses of state-based federalism. The paper also suggests that a constitution for private lawmaking, or a similar system of meta-rules, may be necessary to allow private lawmaking to come closest to its potential.

In a far flung, free society, the federalist values are enduring. They call upon a people to achieve a unity sufficient to resist their common perils and advance their common welfare, without undue sacrifice of their diversities and the creative energies to which diversity gives rise.

This paper attempts to assess privately made law (or private lawmaking) as a kind of federalism, thus taking up a point floated briefly in an earlier article. ${ }^{2} \mathrm{~A}$ very questionable legitimacy is the main challenge for private lawmaking. Competition, or its governmental equivalent-federalism - may help legitimate what otherwise might appear to be an unseemly enterprise by which de facto laws are made outside the structures of democracy or any other government. Because private lawmaking happens without established structures and depends on ad hoc combinations of private actors, I refer to what occurs in the private realm as molecular federalism. James Madison envisioned the United States as a "compound republic," and conceptualizing private lawmaking as molecular federalism follows his compound analogy. The metaphor of the molecule (as opposed to the atom) invokes the idea of a compound because private lawmaking can only occur as a cooperative effort of at least two actors, and usually many more. This figure thus recognizes that even privately made law is a social function.

Aside from serving as a template with which to assess the legitimacy of private lawmaking, federalism can also help uncover the dynamics of different kinds of private lawmaking. The complex of governmental and private relationships in a federalist system, which has received careful analysis for many decades, can show how different lawmaking entities-public and private-influence and react to each other. Further, as the scholarly treatments of federalism have shown, a federalist organization of government is hardly perfect. Bringing this learning about federalism to bear on private lawmaking can help reveal some of the strengths and weaknesses of allowing rule generation to reside in the private sphere.

1. Herbert Wechsler, The Political Safeguards of Federalism: The Rôle of the States in the Composition and Selection of the National Government, 54 Colum. L. Rev. 543, 543 (1954).

2. David V. Snyder, Private Lawmaking, 64 Oнго ST. L.J. 371,437 (2003).

3. The Federalist No. 51, at 323 (James Madison) (Clinton Rossiter ed., 1961). 
Finally, the "compound" idea of the molecule and of federalism may be consonant with some of the German systems theorists' emphasis on what they call "communications." In fact, the notion of molecular federalism may be linked with the idea of "societal constitutionalism" suggested by David Sciulli and expounded by Gunther Teubner. This link is probably most apparent in Professor Teubner's reformulation of Grotius's dictum ubi societas ibi ius: "Law-making also takes place outside the classical sources of international law, in agreements between global players, in private market regulation by multi-national concerns, internal regulations of international organisations, inter-organisational negotiating systems, world-wide standardisation processes that come about partly in markets, partly in processes of negotiation among organisations." ${ }^{\prime 6}$ This conception describes well at least the international aspects of private lawmaking and can be applied almost as easily to domestic private lawmaking too.

This paper does not aim at high theory; instead, it concentrates on the checks and balances, and the particular costs and benefits, associated with allocating power across a shifting hierarchy of public and private lawmakers. Still, this exercise can be seen as an early cut at some of the issues embedded in the "difficult empirical and normative question" that Professor Teubner poses: "How ... political and autonomous social constitutionalisation" actually takes place. ${ }^{7}$ Because of strict space limitations, this paper considers the federalism of the United States and private lawmaking in the commercial or business sphere. Even within that scope, the paper is confined to a brief, essayistic treatment. It also omits some important international issues, including the kind of federalism or regulatory competition that arguably exists in Europe ${ }^{8}$ as well as the complex analysis that would

4. See, e.g., Niklas Luhmann, Law as a Social System (Fatima Kastner et al. eds., Klaus A. Ziegert trans., 2004) (1993) (discussing how society performs through its communications in modern systems theory).

5. David Sciulli, Theory of Societal Constitutionalism: Foundations of a Non-Marxist Critical Theory (1992), cited in Gunther Teubner, Societal Constitutionalism: Alternatives to StateCentred Constitutional Theory?, in Transnational Governance and Constitutionalism 3, 10 (Christian Joerges, Inger-Johanne Sand \& Gunther Teubner eds., 2004). I am grateful to Professor Fernanda Nicola for bringing this Storrs lecture to my attention.

6. Teubner, supra note 5 , at 16.

7. Id. at 17.

8. For good entries into the literature, see, for example, Bruno S. Frey \& Reiner Eichenberger, The New Democratic Federalism for Europe: Functional, Overlapping and ComPETING Jurisdictions (1999), and more recently, Klaus Heine, Interjurisdictional Competition and the Allocation of Constitutional Rights: A Research Note, 26 INr'L Rev. L. \& Econ. 33 (2006), and with respect to corporate law particularly, Ehud Kamar, Beyond Competition for Incorporations, 94 GEo. L.J. 1725 (2006). Also note the symposium entitled "The New Federalism: Plural Gover- 
be required to put together the rules of private international law with the idea of molecular federalism.

\section{A Conception of Private Lawmaking}

The idea of private lawmaking, as the phrase is used here, is explained at length in my previous article. ${ }^{9}$ To summarize, the meaning of law is understood in the tradition of legal realism and is adapted from Holmes and Llewellyn: law is simply a prediction about what an authoritative decision maker will do about a dispute..$^{10}$ Private lawmaking, roughly, is the process by which private actors, or more often, groups of private actors, make rules that de facto bind, or significantly affect, large groups.

The purest form of private lawmaking is a process in which a private group makes rules that bind others without the others' specific consent. This form involves the same dynamic as public lawmaking where Congress and the President together make laws that bind all United States citizens without any specific consent by each citizen to that particular law. An example of this form of private lawmaking is the binding effect of certain interbank agreements. For example, under Uniform Commercial Code $\S 4-103(b),{ }^{11}$ agreements by banks setting checkclearing policies can bind everyone who writes checks, regardless of whether the check writers agree to these rules. So-called self-regulatory organizations like the New York Stock Exchange may also fit this model, as do similarly important but less well-known organizations that govern accounting and auditing standards (e.g., the Financial Accounting Standards Board, a private-sector organization

nance in a Decentered World," held at Emory Law School on February 23, 2007. Unfortunately, that symposium occurred too late to be taken into account in this article.

9. Snyder, supra note 2. For further discussion of private government and lawmaking, see Stewart Macaulay, Private Government, in Law and the Social Sciences 445 (Leon Lipson \& Stanton Wheeler eds., 1986).

10. K.N. Llewellyn, The Bramble Bush: On Our Law and Its Study 3 (1930) ("This doing of something about disputes, this doing of it reasonably, is the business of law. And the people who have the doing in charge, whether they be judges or sheriffs or clerks or jailers or lawyers, are officials of the law. What these officials do about disputes is, to my mind, the law itself."); Oliver Wendell Holmes, Jr., Address at Boston University School of Law: The Path of the Law (Jan. 8, 1897), in 10 Harv. L. Rev. 457, 458 (1897) ("a legal duty so called is nothing but a prediction that if a man does or omits certain things he will be made to suffer in this or that way by judgment of the court; and so of a legal right").

11. "Federal Reserve regulations and operating circulars, clearing-house rules, and the like have the effect of agreements under subsection (a), whether or not specifically assented to by all parties interested in items handled." U.C.C. § 4-103(b) (2005). 
whose arguable failures led to the public creation of another private board, the Public Company Accounting Oversight Board)..$^{12}$ The rules privately made by these organizations are frequently given formal legal authority by government action, ${ }^{13}$ so these rules sometimes blend into the next category.

In a less pure form of private lawmaking, a private group makes rules that will generally bind others, but a formal public intermediation is required, as where public legislatures adopt privately drafted codes and model laws, or where public courts adopt and apply privately drafted restatements and principles. The American Law Institute and the National Conference of Commissioners on Uniform States Laws (NCCUSL) exemplify this kind of private lawmaking, and they are the best known and most studied of U.S. private legislatures.

Another form of private lawmaking involves a private entity that will make rules that bind others through thousands or millions of adhesionary contracts. Credit card agreements are a prime example, but there are countless others, including warranties given by large sellers like automobile manufacturers. Rules made by trade associations, such as the International Chamber of Commerce rules for letters of credit (UCP), can also fit in this category. The rulebooks promulgated by such organizations are often incorporated by reference into thousands or millions of contracts. There are innumerable other examples of private lawmaking, ranging from homeowners' associations to trade associations to standard-setting organizations and so on. ${ }^{14}$

\section{Federalism and Private Lawmaking}

Federalism in the United States operates on two axes. The vertical axis describes the hierarchical relationship between the national and the state governments; the horizontal axis describes the relationship between the states, which are set up independently of each other. Each of these dimensions carries several characteristics, such as the possibility of competition between states and the power of one government to check another. This part of the paper introduces each of these dimensions and aspects of federalism and considers how each applies to private lawmaking.

12. Sarbanes-Oxley Act of 2002, 15 U.S.C. $\$ 7211$ (2002).

13. E.g., Interpretive Releases Relating to Accounting Matters, Statement of Policy on Establishment and Improvement of Accounting Principles and Standards, Accounting Series Release No. 150, 39 Fed. Reg. 1260 (Dec. 20, 1973) (adopting the standards of the FASB).

14. Except as noted above, each of these examples is explained further, with ample citation, in Snyder, supra note 2, at 378-402. 


\section{A. Vertical Federalism}

\section{The Idea of Verticality}

Vertical federalism refers to the relationship between the states and the national government. The label makes the hierarchy explicit; the states are placed below the federal government, and thus state law is subject to preemption by federal law, including federal legislation and regulation. ${ }^{15}$ In this sense, the national government and all of its many entities with regulatory authority, exercising supreme power, can check state governmental actions. Less obviously, the states can also serve as a check on the national government in some circumstances. From a formalistic and structural view, the national government is supreme only within the confines of its purposely limited powers. Under the Tenth Amendment, "The powers not delegated to the United States by the Constitution, nor prohibited by it to the States, are reserved to the States respectively, or to the people." ${ }^{16}$ Largely ignored or repressed during the generations since the New Deal, these ideas of federalism-i.e., limited federal power--became more important again under the Rehnquist Court. ${ }^{17}$

There are at least two other prominent theories on how states can serve as a democratic check on the federal government. The first is associated with an idea that the late Justice Brennan propounded when he thought the Burger Court was

15. See the Supremacy Clause, for example, U.S. Const. art. VI, cl. 2. Note the importance of understanding preemption doctrine as part of federalism. See, e.g., Samuel Issacharoff \& Catherine M. Sharkey, Backdoor Federalization, 53 UCLA L. Rev. 1353 (2006).

16. U.S. Const. amend. X; see also U.S. Const. amend. XI (restraining federal judicial power in cases against states); U.S. Const. amend. IX (reserving unenumerated rights to the people).

17. A century ago, of course, the law was different, and the Supreme Court found various robust constitutional constraints on governmental power. These views were then famously rejected in the New Deal era. Thus Lochner v. New York, 198 U.S. 45 (1905), and similar cases lost their footing in West Coast Hotel Co. v. Parrish, 300 U.S. 379, 391 (1937) (implicitly overruling Lochnerera cases), and United States v. Carolene Products Co., 304 U.S. 144, 152 (1938) (declaring a need for judicial deference to economic regulations). A recently more invigorated federalism under the Tenth Amendment can be seen in the dynamics reflected by the following cases. E.g., Nat'l League of Cities v. Usery, 426 U.S. 833 (1976), overruled by Garcia v. San Antonio Metro. Transit Auth., 469 U.S. 528, 531 (1985); New York v. United States, 505 U.S. 144 (1992) (which seems to have reservations about Garcia); Printz v. United States, 521 U.S. 898 (1997); United States v. Lopez, 514 U.S. 549, 561 (1995) (asserting Gun-Free School Zones Act not within federal power); United States v. Morrison, 529 U.S. 598, 613 (2000) (stating Violence Against Women Act not within federal power); see also Seminole Tribe v. Florida, 517 U.S. 44, 47 (1996) (reaffirming broad, extratextual view of state immunity from suit under Eleventh Amendment); Alden v. Maine, 527 U.S. 706 (1999) (reaffirming broad, extratextual view of state immunity from suit under Eleventh Amendment). For an important qualification, see infra notes 28-29 and accompanying text. 
engaged in a retrenchment against individual rights. Brennan argued that state courts should recognize state-based protections of individual rights when no federal right is recognized, noting that several state courts had done so. ${ }^{18}$ The Supreme Court of the United States has no power to reverse these decisions, of course, since they rest on state rather than federal law..$^{19}$ Brennan noted that this state power had been exercised not only in response to the narrower view of federal rights that prevailed in the times after the Warren Court, but also in the long era before the federal Bill of Rights was incorporated against the states. ${ }^{20}$ Brennan thus saw the state and federal courts as providing "a double source of protection" for individual rights through this longstanding mechanism. ${ }^{21}$ Even more significantly for purposes of private lawmaking, Brennan suggested that state courts give greater meaning to the federal Due Process Clause by recognizing property and liberty interests as a matter of state common law. Once state law recognizes those rights-including contract and property rights - they are protected by the federal Due Process guarantee. ${ }^{22}$

A second prominent theory of the state-based check on national power comes from a complex analysis by Herbert Wechsler. Instead of focusing on the courts, he concentrated on the political structure set up by the Constitution. He argued that "the national political process in the United States-and especially the role of the states in the composition and selection of the central government-is intrinsically well adapted to retarding or restraining new intrusions by the center on the domain of the states. ${ }^{23}$ The idea is based on the political reality, recognized across the centuries from James Madison to Tip O'Neill, that even in Congress, politics is more local than national. ${ }^{24}$ Wechsler also thought that the electoral college enhances the power of states_-particularly large states whose electoral votes could

18. William J. Brennan, Jr., State Constitutions and the Protection of Individual Rights, $90 \mathrm{HARv}$. L. Rev. 489, 491, 495, 498-502 (1977).

19. Id. at 501 (citing S. Burlington County NAACP v. Twp. of Mt. Laurel, 423 U.S. 808 (1975)).

20. Id. at 501-02.

21. Id. at 503 .

22. Id.

23. Wechsler, supra note 1, at 558. For an expansion of arguments similar to Brennan's and Wechsler's, see Akhil Reed Amar, Five Views of Federalism: "Converse-1983" in Context, 47 VAND. L. Rev. 1229 (1994) and Akhil Reed Amar, Of Sovereignty and Federalism, 96 Yale L.J. 1425 (1987).

24. E.g., The Federalist No. 46, at 296 (James Madison) (Clinton Rossiter ed., 1961). ("A local spirit will infallibly prevail much more in the members of Congress than a national spirit will prevail in the legislatures of the particular States."); Tip O'Neill \& Gary Hymel, All Politics Is Local And Other Rules of the Game xv-xvi (1994) (explaining the meaning of the lesson that 
sway a presidential election. The argument requires detailed explanation to be clear, but in summary, it rests on a few structural points: (a) the electors for each state vote together; (b) the college cannot elect a president without a majority; and (c) failing a majority, the presidential decision shifts to the House of Representatives, voting by state-a potent, albeit generally dormant, threat.

Although Wechsler devoted the bulk of his influential article to this complicated political and constitutional analysis, he also made another point first, perhaps thinking it the strongest: the states are protected because they exist and exercise their powers. Wechsler did not attempt to elaborate or justify the point further, but to my mind (and apparently to his), it has great intuitive plausibility. It also works well with what seems to be the essential idea in his article, which is that the national government often finds interference with state law, except for interstitial regulation, to be inexpedient. For example, one of the clearest and best known areas of competence for the national government is the regulation of interstate commerce under the Commerce Clause. ${ }^{25}$ The courts have given this Clause an extraordinarily expansive reading, ${ }^{26}$ and contracts and commercial transactions easily fall within this core federal power. Yet Congress still leaves systematic regulation of those activities to the states, with only piecemeal adjustment through national legislation.

Even a brisk description, then, shows a vertical relationship that is characterized by more than a straight, top-down, preemptive dynamic. Although there is little doubt about the formal supremacy of the national government and its practical supremacy when it chooses to exercise its power, the national government has shown considerably more restraint than is required by the constitutional principles enunciated by the Supreme Court. (Recall that the Supreme Court has taken a quite liberal view to federal power since the switch during the New Deal, with modest inroads during the tenure of the late Chief Justice Rehnquist.) ${ }^{27}$ Although this restraint may have something to do with principles expressed in the text of the Constitution, and the culture that the venerated text inculcates, it may well have more to do with simple-or not so simple-expedience.

"[a]ll politics is local"). O'Neill served as Speaker of the U.S. House of Representatives from 1977 until his retirement in 1986.

25. U.S. Const. art. I, $\$ 8$, cl. 3.

26. See, e.g., Gonzalez v. Raich, 545 U.S. 1 (2005) (holding that Congress' Commerce Clause authority extends to the power to prohibit local cultivation and use of marijuana).

27. See supra note 17 and accompanying text. 


\section{The Vertical Axis of Molecular Federalism}

To assess how private lawmaking functions along the vertical axis of federalism, we first must keep in mind that the vertical axis of governmental federalism sets up an explicit but complicated hierarchy in which the federal government is "supreme" within its sphere but powerless outside its sphere. The national sphere, as mentioned, includes commerce ${ }^{28}$ and thus encompasses the activities discussed here. The importance of this point is that commercial activities, in terms of government power, may be regulated by the states, the federal government, or both; if the federal government wishes to preempt the states, it can.

Private lawmaking, at first blush, would appear to be at the bottom of the hierarchy, with the state, and ultimately the federal government, both placed higher. In other words, private lawmaking could be displaced either by state or by federal lawmaking-a reassuring point given concerns about the legitimacy of private lawmaking. Often both state and federal law, and sometimes local law, can thus check private lawmaking. In the usual run of cases, private lawmaking is easier to displace than governmental lawmaking, and the displacement is less constitutionally fraught than in the governmental realm. Although power struggles between the state and national government can sometimes raise issues of constitutional moment and has occasioned one of the most (in)famous short-term reversals in Supreme Court precedent, ${ }^{29}$ the displacement of privately made law rarely implicates such issues as long as the legislation is prospective. Not since the Lochner era has the Constitution been read to protect prospective freedom of contract, assuming the governmental regulation can pass the extremely deferential rational basis scrutiny.$^{30}$ Because of the vertical dimension of federalism, government regulation can easily displace private lawmaking.

This displacement may happen in different ways, and different methods of regulation may ameliorate different problems of private lawmaking. Through substan-

28. See U.S. Const. art. $1, \S 8$, cl. 3 . Any doubts about the breadth of national power to regulate commerce were put to rest in Gonzales v. Raich, 545 U.S. 1 (2005).

29. See Nat'l League of Cities v. Usery, 426 U.S. 833 (1976), overruled by Garcia v. San Antonio Metro. Transit Auth., 469 U.S. 528 (1985); see also Printz v. United States, 521 U.S. 898 (1997); New York v. United States, 505 U.S. 144 (1992) (seemingly in tension with Garcia). For further discussion on this topic, see supra note 17 and accompanying text.

30. For the path to the demise of the Lochner era and the advent of judicial deference to economic regulation, see cases cited supra note 17. The Contract Clause, U.S. Const. art. I, § 10, cl. 1 ("No State shall ... pass any ... law impairing the Obligation of Contracts"), is interpreted to be limited to state or local laws that interfere with existing contracts. Ogden v. Saunders, 25 U.S. 213 (1827). 
tive regulation and displacement, of course, public lawmakers can outright override private lawmaking with mandatory rules, either partially or entirely. Through procedural regulation, public lawmakers may regulate the process of private lawmaking by encouraging competition or prohibiting moves that will lead to dominance. Enforcement of the antitrust laws, despite current exemptions for many private lawmaking activities, would be an example. ${ }^{31}$ Finally, through procedural displacement, public lawmakers might completely control the process for rule generation. For instance, this method is sometimes used in standard setting. ${ }^{32}$

\section{The Surprising, Shifting Hierarchy of Molecular Federalism}

Any concerns about the illegitimate exercise of private power through private lawmaking, it appears at first, are subject to a double check by the state and national government. Experience shows, however, that this theory leaves out important dynamics of commercial law and federalism, and these dynamics can cause private lawmaking to jump places in the hierarchy in at least two ways. First, the shift can happen smoothly and in an almost planned way. Much publicly made commercial law consists of default rules, and they are by their nature subject to displacement by private agreement, including the kinds of agreements that we consider private lawmaking. The observation that the bulk of commercial law consists of default rules is now perhaps commonplace. Some scholars go further, arguing that some of these default rules actually encourage private displacement, as is the case with "penalty default rules." With such rules, the law by default sets a contract term in a way that would penalize one or both parties, thus encouraging them to reach an agreement to displace the default rule. This strategy would force parties to disclose information to each other and to bargain over the term, both of which might be seen as beneficial. ${ }^{33}$ Yet regardless of this strong-form default strategy, publicly made law is often designed to bow to private agreements and thus to privately made law.

31. See generally Christopher L. Sagers, Antitrust Immunity and Standard Setting Organizations: A Case Study in the Public-Private Distinction, 25 Cardozo L. Rev. 1393 (2004) (discussing how the distinction between "public" and "private" has caused negative consequences in the realm of antitrust law).

32. See Ronald J. Mann \& Jane K. Winn, Electronic Commerce 390-91 (2002).

33. The scholarship on default rules is vast, and even that on penalty defaults is considerable. For the seminal article in this area, see Ian Ayres \& Robert Gertner, Filling Gaps in Incomplete Contracts: An Economic Theory of Default Rules, 99 YALE L.J. 87 (1989). For additional and very recent discussion on this topic, see Symposium, Default Rules in Private and Public Law, 33 Fla. ST. U. L. Rev. 557 (2006). 
Second, a more jarring shift in the hierarchy can occur in an entirely different way. Consider the rules made by banks, and especially by associations of large banks. At first blush, state and federal lawmaking can check private lawmaking. A state that attempts to regulate private lawmaking, however, may itself be displaced by a federal law that validates private lawmaking despite the attempts of the would-be regulating state. For example, banks that issue credit cards-generally as part of bank associations that do business under the Visa or MasterCard brands-frequently elect to be chartered as "national banks" and thus become entitled to the protections of the National Bank Act. One key function of the National Bank Act and the federal agency charged with its administration, the Office of the Comptroller of the Currency (OCC), is to protect national banks from much state regulation. Thus, in issuing its Visa card, a bank that is legally located in South Dakota or Delaware may freely violate usury laws, or even laws regulating many other terms, such as late fees and the like, in other states. ${ }^{34}$ The law implemented by the tens of millions of private contracts entered between such banks and their credit-card customers is therefore superior to the state law in those other states. This repositioning of the hierarchy so that private lawmaking becomes superior to state lawmaking is always possible in the commercial field because it is within the federal Commerce Clause power. ${ }^{35}$ To be sure, the national government must act-through an instrument such as the National Bank Act-to achieve this result. But in the commercial realm, such action is always possible under current interpretations of constitutional principles, and the effects of even a single act and a single federal regulatory agency can be far-reaching.

On this understanding, then, most of Brennan's arguments about federalism do not hold. He supposed that the national constitution would establish a floor of immutable individual rights, and that state constitutions could provide more rights, through their text and through interpretation by state courts. While this analysis works for constitutional rights, it dissolves when the rights are not of con-

34. See Marquette Nat'l Bank v. First of Omaha Serv. Corp., 439 U.S. 299, 308 (1978) (holding that a national bank can export its interest rates to other states, as long as the interest rates are legal in the home state of the bank). In response to litigation claiming that Citibank late fees were not interest and thus not protected by Marquette, the OCC promulgated a regulation protecting the bank, 12 C.F.R. $\S 7.4001$ (2001), an action which was not only upheld but which received significant judicial deference. See Smiley v. Citibank, 517 U.S. 735, 739-40 (1996).

35. One might analogize the shifting hierarchies in this complex federalist scheme to the shifting legal hierarchies forced by further outgrowth of law and society, not just into the then-nearlyunimaginable size of the United States, but now into the global context. See generally Gunther Teubner, The King's Many Bodies: The Self-Deconstruction of Law's Hierarchy, 31 Law \& Soc'y Rev. 763 (1997) (discussing the deconstruction of the law's hierarchy occurring through globalization). 
stitutional stature. Although in many cases there will indeed be "a double source of protection," ${ }^{36}$ the national government can elect to withhold its own protection and to prevent the states from extending any. In the absence of constitutional strictures (and there are few in the commercial realm), ${ }^{37}$ private lawmaking is subject to a critique based on individual rights.

In the context of private lawmaking, one of Brennan's arguments actually works in what he may have regarded as a perverse way. He suggested that state courts, just through the development of common law (without the need to resort to constitutional law), could recognize property and liberty interests. Such expanding recognition would presumably afford greater status to the contract rights that are the product of private lawmaking. In this way, laws that are privately made through contract, once those contract rights are recognized as a kind of property interest, are themselves protected under the federal Due Process Clause. In this way, it is true that the apparently lowest rung on the hierarchical ladderthe contracts of private actors - can act as a check on federal legislative action, although the Due Process guarantees for economic rights are relatively minimal. Of course, the normative valence of this shift in the hierarchy will depend on whether freedom of contract, as exercised in private lawmaking, is a right more important than the various rights (e.g., protection from usury) that can get trampled in the process. That is a question beyond the scope of the present paper.

Moving to the political (as opposed to rights-based) views on federalism, Wechsler's ideas seem to hold in a general, but not a particular, sense. He understood the political process, as structured by the Constitution, to resist new intrusions by the center. The hierarchy shift, which presumably occurs at political instance, shows how some players can protect their freedom both from the states and from the national government by appealing to the national government. $\mathrm{Cu}$ riously, both banks and consumers have found this strategy successful, ${ }^{38}$ a fact that may reflect happenstance, changing political times, or a structural effect. In this

36. An important recent example is the campaign by the former Attorney General of New York, Eliot Spitzer, to enforce laws against corporate and securities fraud that could have also been enforced by the national authorities (and in particular, by the Securities and Exchange Commission).

37. See cases cited supra note 17 and accompanying text.

38. An example on the consumer side is the Magnuson-Moss Warranty-Federal Trade Commission Improvements Act, 15 U.S.C. \$§ 2301-2312 (1975), which purposefully displaces inconsistent state law allowing sellers to disclaim certain warranties. For an explanation of the political processes on the consumer side, see, for example, Kathleen Patchel, Interest Group Politics, Federalism, and the Uniform Law Process: Some Lessons from the Uniform Commercial Code, 78 Minn. L. Rev. 83 (1993). For a comparison between the uniform law drafting process and the public, espe- 
context, however, Wechsler has not proven correct in the particulars. He saw the political structure as tilted toward protecting state power against the national government. These instances suggest that private power has successfully invoked political processes to defend itself from national and state governance.

\section{B. Horizontal Federalism}

\section{The Basics of Horizontal Federalism}

Horizontal federalism refers to state powers in relation to the other states. This relationship has several famous facets. States can serve as laboratories of democracy, attempting different solutions to problems, without dragging the whole country into the experiment. ${ }^{39}$ This advantage is not merely theoretical; several crucial and successful national efforts originated in this way, including women's suffrage, unemployment insurance, and minimum wage laws. ${ }^{40} \mathrm{~A}$ related, more economically oriented idea suggests that the states form a marketplace for democracy, where the states compete for customers (residents and/or taxpayers, and hence power and/or money) with different laws. Theories differ, but one can argue that states compete for valuable migrants by offering good economies and efficient laws, or for more votes by seeking migrants who like welfare benefits and/or high taxes, or for migrants with high human capital by offering a haven from earlier creditors. ${ }^{41}$ I will refer to these two ideas as the "laboratory" and the "marketplace" aspects of federalism.

In addition, horizontal federalism can help achieve a kind of lawmaking that accommodates the logistical difficulties of a large and geographically dispersed citizenry. With smaller and more decentralized governments, the government is closer and more responsive to the people, and the people have easier access to and a more particular stake in the government. Being closer to the people, government is presumably more participatory, and the people can become better educated about what their government is doing. "Power to the people," goes the

cially congressional, legislative process, see Gail Hillebrand, What's Wrong with the Uniform Law Process?, 52 Hastings L.J. 631, 635-38 (2001).

39. New State Ice Co. v. Liebmann, 285 U.S. 262, 311 (1932) (Brandeis, J., dissenting).

40. See Fed. Energy Regulatory Comm'n v. Mississippi, 456 U.S. 742, 788-91 (1982) (O'Connor, $\mathrm{J}$., concurring in the judgment in part and dissenting in part).

41. See generally Margaret F. Brinig \& F.H. Buckley, The Market for Deadbeats, 25 J. Lecal Stud. 201, 201 (1996) (outlining these three explanations for why states seek migrant workers).

42. Cf. Amar, Five Views of Federalism, supra note 23, at 1233-34 (linking these attributes to the laboratory metaphor). 
slogan. This structure should also alleviate some collective action problems because the people's interests are less diffuse. Similarly, different segments of society have different problems and would benefit from the possibility of different solutions. Diverse solutions are more likely under a regime of federalism. A segmented governmental organization allows a relatively appropriate and robust response to local problems when otherwise there would be (a) no response because of the dominance of those who do not suffer the problem, (b) a weak response because of a necessary compromise with those who do not suffer the problem, or (c) an inappropriately strong response, where those who do not suffer the problem must nevertheless pay the costs of the solution. Examples include rent and water controls. Some places arguably need them, some places do not-or need controls of a different kind. Federalism allows diverse laws for diverse needs.

Although federalism is characterized by these different benefits, a number of recognized problems beset different aspects of federalism. ${ }^{43}$ First, certain kinds of competitions can create a "market for lemons." This can happen when consumers do not have enough information about quality and are therefore unwilling to pay for higher quality. ${ }^{44}$ Perhaps because of this dynamic, citizens--i.e., consumers of laws-may suffer from a race to the bottom where small groups who have incentives to become well informed take advantage of larger groups with larger but more diffuse interests. Many have argued that this situation has occasioned just such a "race to the bottom" in corporate law, although there is substantial scholarly disagreement. ${ }^{45}$ In addition, the horizontal division of power among the states can lead to spillover effects (most obviously, for example, one state sending its pollution downwind into another state). In democratic terms, this problem reflects a lack of representation. In economic terms, it is a problem of externalities. Finally, the multiplicity of lawmakers can deprive society of the benefits of coordination.

43. E.g., Vicki C. Jackson, Federalism and the Uses and Limits of Law: Printz and Principle?, 111 Harv. L. Rev. 2180 (1998); Edward L. Rubin \& Malcolm Feeley, Federalism: Some Notes on a National Neurosis, 41 UCLA L. Rev. 903 (1994); see also Frank B. Cross, The Folly of Federalism, 24 CArdozo L. Rev. 1 (2002) (containing helpful citations to the literature).

44. George A. Akerlof, The Market for "Lemons": Quality Uncertainty and the Market Mechanism, 84 Q. J. Econ. 488, 488 (1970).

45. E.g., Lucian A. Bebchuk \& Assaf Hamdani, Federal Corporate Law: Lessons from History, 106 Colum. L. Rev. 1793 (2006); William L. Cary, Federalism and Corporate Law: Reflections Upon Delaware, 83 Y ALE L.J. 663 (1974); Roberta Romano, Law as a Product: Some Pieces of the Incorporation Puzzle, 1 J.L. Econ. \& Orc. 225 (1985); Ralph K. Winter, Jr., State Law, Shareholder Protection, and the Theory of the Corporation, 6 J. Legal Stud. 251 (1977). See also Roberta Romano, The Genius of A merican Corporate Law 14-24 (1993) (providing an overview of Cary and Winter's a rguments). 
A unified approach to lawmaking may be required to achieve the efficiencies of uniformity in national and international markets. Along similar lines, some lawmaking contexts may be situarions of natural monopolies, where regulatory competition may be difficult or impossible, and in any event, an inferior arrangement to a single legal regime.

\section{The Horizontal Dimension of Molecular Federalism}

In many ways, private lawmaking is particularly strong along the horizontal axis, largely because private lawmaking can be segmented, and then infinitely and constantly rearranged to meet particular and changing needs. Private lawmaking is literally boundless, in that it is not tied to geographical boundaries. And it is flexible: private lawmaking can adapt to different situations in different ways. Letters of credit can be governed by rules that are different both in substance and extent from credit cards, for instance (although the two credit devices are actually quite similar), and these rules may — and do_-come from different combinations of private actors. A problem does not have to be solved by a particular political entity; a new private lawmaking entity, or entities, can arise for each situation that would benefit from rules. These points are a leading argument for private lawmaking, although they will also need to be qualified, as will be noted in part III of this article.

The related laboratory and marketplace categories show private lawmaking in perhaps its most flattering light, allowing practically infinite possibilities for experimentation and countless potential competitions. In economic terms, there is a tremendous increase in the "supply" of laws available. ${ }^{46}$ Examples abound-even in some areas that seemed to be under the unbreakable domination of one group, as with diamond trading. The apparently impregnable dominance of the extraordinarily homogeneous and insular ultra-Orthodox Jews has suffered significant inroads by entirely alternative groups under a different (non-state) regime. ${ }^{47}$ Other

46. Economists generally seem to agree on the efficiency of permitting choice of law, a point closely related to the dynamics of private lawmaking, although the view is not shared universally, particularly by those with radical perspectives. E.g., Larry E. Ribstein, Choosing Law by Contract, 18 J. Corp. L. 245, 246 (1993). For a recent collection of authorities, see Giesela Rühl, Party Autonomy in the Private International Law of Contracts: Transatlantic Convergence and Economic Efficiency 32, nn.109-10 (Comparative Research in Law \& Political Econ., Research Paper No. 4/2007, 2007), available at http://www.comparativeresearch.net/main.php?page= papers.php.

47. Barak D. Richman, Ethnic Networks, Extralegal Certainty, and Globalisation: Peering into the Diamond Industry, in Legal Certainty Beyond the State (Volkmar Gessner ed., forthcoming 2007). Compare Barak D. Richman, How Communities Create Economic Advantage: Jewish Diamond Merchants in New York, 31 LAw \& Soc. INQuiry 383, 409-11 (2006) (noting the importance of the Palanpuri Jain and other Indians in the diamond industry) with Lisa Bernstein, Opting Out of 
more purely legal competitions may be observed in the promulgation of competing private or quasi-private international contract law regimes, such as the Unidroit Principles of International Commercial Contracts and the Principles of European Contract Law, both of which would seem to compete with the United Nations Convention on Contracts for the International Sale of Goods, as well as with domestic law. The existence of these examples shows that at least in some contexts, a real regulatory competition is possible, and the benefits of that competition can be realized. ${ }^{48}$

Private lawmaking also breaks what Akhil Amar calls "the seeming statism of the laboratory perspective ${ }^{n 9}$ and can arguably liberate lawmaking from the sometimes crippling power of the entrenched interests that dominate public sector controls. ${ }^{50}$ This break from statism and its encrusted interests leads to the separate point, which I have called "power to the people," that private lawmaking empowers the people as lawmakers for themselves. This sort of shift from the state and the creation of a space for private combinations realizes the possibility seen by the French reformers who envisioned contract as a lawmaking opportunity for any individual who could find a contracting partner. The parties can make the law for themselves in their contract (subject to various obvious constraints). ${ }^{51}$

On a larger scale, beyond the basic combination of the two-party contract, private lawmaking has great potential to realize some of the benefits of democratic theory, and in this way achieve greater legitimacy. When private lawmaking is the result of the efforts of the group affected by the rules, it provides a strong example of the kind of democracy expounded by John Dewey and now by the democratic experimentalists. Not only do the people affected become better educated about their private government and its rules, but the private government itself is better placed to learn how its rules can be improved in light of experience. This structure thus can

the Legal System: Extralegal Contractual Relations in the Diamond Industry, 21 J. LEG. STud. 115, 115 (1992) (explaining why a system of private governance has developed and flourished within the diamond industry).

48. For a collection of authorities on regulatory competition, see Gralf-Peter Calliess, The Making of Transnational Contract Law, 14 Ind. J. Global Legal Stud. 469, 481 n.55 (2007).

49. Amar, Five Views of Federalism, supra note 23, at 1245.

50. Peter Vincent-Jones, The New Public Contracting: Public Versus Private Ordering?, 14 IND. J. Global Legal Stud. 259, 266 nn. 22-23; see also Peter Vincent-Jones, The New Public Contracting: Regulation, Responsiveness, Relationality 117-37 (2006) (questioning whether the trenches can be broken as moves toward decentralization are countered by moves toward centralization).

51. C. crv. art. 1134 (Fr.) ("Les conventions légalement formées tiennent lieu de loi à ceux qui les ont faites."). 
provide a better opportunity for what these theorists would call "experiment," "irritation," and correction. ${ }^{52}$ In other words, the private government is an organic part of the governed body, and it can learn from experience. Similarly, breaking down the scale of lawmaking from its traditional embodiment in great governmental institutions allows for more immediate responsiveness and allows the lawmaking process to take advantage of the benefits of Ian Macneil's relational contract theory. As Peter Vincent-Jones points out, "where the mode of economic organization is contractual, the capacity for collective learning among the parties involved in the contracting regime is likely to be dependent on the quality of relationality in the constituent regulatory relationships. ${ }^{\text {'53 }}$ Interestingly, the European Commission is seeking to find ways to translate this apparent benefit of private lawmaking into the public sphere under the rubric of "reflexive governance," as explained more fully elsewhere in this Symposium. ${ }^{54}$

With respect to the diversity aspect of federalism, private lawmaking is perhaps at its strongest, given its ability to make rules for different needs. In a way, this is the identity of private lawmaking, whether at the simplest level of the twoparty contract or in the wider reaching versions of private lawmaking, where rules can be-and are-made for particular but wide-ranging contexts (such as letters of credit, which are a very particular credit device that are economically important across the entire globe). ${ }^{55}$ The fact and the moral dictates of diversity also provide one of the crucial arguments for federalism in general and for private lawmaking in particular. Both of these strategies of organization can help address the problems, raised by both the left and right, of grossly inefficient central planning and of the repugnant subjection of diverse actors to a single recognized pattern in which not everyone fits. ${ }^{56}$ Here, private lawmaking has a particular

52. For an introduction to the ideas of the democratic experimentalists, see, for example Michael C. Dorf \& Charles F. Sabel, $A$ Constitution of Democratic Experimentalism, 98 Colum. L. Rev. 267 (1998). For a more recent work, and particularly for ideas on implementing Dewey's thought, see William H. Simon, Faculty Speaker Series Lecture at American University Washington College of Law: The Institutional Configuration of Deweyan Dernocracy (2006).

53. Vincent-Jones, supra note 50, at 273 n.52.

54. See id. at 268 (citing European Commission, 6th Framework Program Integrated Project: Reflexive Governance in the Public Interest, http://refgov.cpdr.ucl.ac.be (last visited Apr. 4, 2007)).

55. See Snyder, supra note 2, at 389-95; see also Gillian Hadfield \& Eric Talley, On Public Versus Private Provision of Corporate Law, 22 J.L. Econ. \& ORG. 414 (2006) (discussing why private law may be better than public law in some circumstances).

56. For the perspective on the left, see David Campbell, Relational Contract and the Nature of Private Ordering: A Comment on Vincent-Jones, 14 Ind. J. Global Legal Stud. 279, at 294-95, 298-99 
advantage over state-based federalism because private lawmaking is extraterritorial, or in other words, it has a nonspatial dimension. Parties can opt into a regime regardless of their location.

This extraterritorial aspect of molecular federalism is particularly important in many arenas, commercial and otherwise. The Internet is the most prominent current example, and examples of private lawmaking regimes-primarily sealtype programs - abound..$^{57}$ More fundamentally, some scholars have claimed that computer code is itself a kind of private lawmaking too, ${ }^{58}$ and recent events might be cited in support of the idea. Microsoft is now encouraging the use of code to do a kind of job we typically associate with the law: consumer protection. The company, based on what it perceives as market demand, is promoting particular software structures to protect the privacy of end users. ${ }^{59}$ Others, outside the virtual world of computers and the Internet, have pointed to a different extraterritorial approach to private lawmaking. Just as it may be difficult to mount the necessary political support to provide sufficient state-based computer privacy protection, it may be difficult because of geographic dispersal to pass nondiscrimination laws related to sexual orientation. But a seal program can allow dispersed parties to opt into an extraterritorial legal regime that prohibits such discrimination and that channels the benefits of the nondiscrimination to those who opt in. ${ }^{60}$ Finally, extraterritoriality helps level the field for enterprises of different sizes. With territorial legal regimes, large enterprises can escape mandatory rules by leaving the jurisdiction, just as many credit card banks put credit card entities in Delaware or South Dakota. If players could opt into regimes without relocation, barriers to entry would be lower and competition more robust. Of course, at the same time, regulation would be more difficult.

One separate, more conjectural idea also bears noting: Private lawmaking may be nimbler than state-based federalism. Outside the public government, there are fewer obstacles to making new laws, and smaller lawmaking entities should be able to undo old laws more easily than is possible for a public legislature whose interests

(2007). For the classic statement on the right, see Robert Nozick, Anarchy, State, And Utopia 88-90 (1974).

57. See Snyder, supra note 2, at 444.

58. See, e.g., Lawrence Lessig, Code And Other Laws of Cyberspace 6 (1999); Teubner, supra note 5 , at 8 n.19.

59. See Consumer Protection -Privacy: Microsoft Guidelines for Software Makers Aim to Improve, Standardize User Experience, 75 U.S.L.W. 2244, Oct. 31, 2006.

60. See Ian Ayres \& Jennifer Gerarda Brown, Straightforward: How to Mobilize HeteroSEXUAL SupPort for GAY Rights 79-94 (2005). 
are so much larger. This conjecture would seem strongest when money is at stake: "Politicians and bureaucrats do not evaluate and pursue innovations in law in the way that entrepreneurs do - with the speed, flexibility, resources, and incentives of the market at their disposal.' ${ }^{\prime 61}$ This intuition is certainly subject to question, however. For instance, the sovereign debt market's standard contract terms, which have been considered a private lawmaking regime, provide examples that go in both directions. To support the intuition, one might point to the introduction of clauses that allow key financial terms to be changed with just 75 percent (instead of unanimous) consent. This innovation was aimed at an important holdout problem that public lawmakers had seemed incapable of addressing. On the other hand, when a new standard rule became necessary because of an interpretive shock, no new rule was introduced, leading some to argue that change in privately made standard terms seems to happen "rarely, slowly and quietly."

\section{Extending the Horizon of Horizontal Federalism: The International Element}

Although federalism in the United States contemplates a largely closed system of governance, private lawmaking is not so limited..$^{63}$ Thus, U.S. constitutional federalism fails to capture the international and nongovernmental dynamics of private lawmaking. In other words, it does not deal with the possibility of heterarchy (i.e., rule by another).

Some of the dynamics in the international sphere are similar to those in the domestic sphere. In both spheres, parties can choose from familiar choices within the confines of U.S. federalism or from the wider options available globally. Corporate law and securities offerings illustrate the point. Just as a business whose operations are in Iowa may incorporate in Delaware, and thus subject itself to the corporate law of Delaware instead of that of Iowa, a Russian business may offer its financial securities in New York, London, or both, subjecting itself to securities regulation wherever it chooses. ${ }^{64}$ For some companies, high legal requirements

61. Gillian K. Hadfield, Privatizing Commercial Law, Regulation, Spring 2001, at 40, 41. Compare Gillian K. Hadfield, Privatizing Commercial Law: Lessons from ICANN, 6 J. SMALL \& EMERGING Bus. L. 257 (2002).

62. Anna Gelpern \& Mitu Gulati, Public Symbol in Private Contract: A Case Study, Wash. U. L. Rev. (forthcoming 2007) (providing a skeptical view of the effectiveness of the $75 \%$ clauses). See Stephen J. Choi \& G. Mitu Gulati, Contract as Statute, 104 Mich. L. Rev. 1129, 1137-38 (2006). For the shocking litigation, see Elliott Assocs. v. Banco de la Nacion, 194 F.3d 363 (2d Cir. 1999).

63. To be clear, the reference to a "closed system" is not intended to invoke the idea of autopoiesis. I leave that argument to others. See, e.g., Lummann, supra note 4.

64. See Stephen J. Choi \& Andrew T. Guzman, Portable Reciprocity: Rethinking the International Reach of Securities Regulation, 71 S. CAL. L. Rev. 903, 907-08, 933 (1998). 
may be attractive, and by opting into an exacting regulatory regime, they send signals about value and transparency. Thus, a foreign company may choose (and many have chosen) to be listed on the New York Stock Exchange under the rules for domestic issuers - rules which are more rigorous than those for foreign issuers. ${ }^{65}$ From the other side of the ocean, though, the London financial market is increasing its penetration into the New York share of the financial markets-largely, it is said, because of the different regulatory regime. ${ }^{66}$ This is the stuff of regulatory competition, whether on the national or the international scale. An offering in London (or elsewhere in the European Union) is hardly a move into a cowboy's freewheeling plain; the difference is not that there is no regulation, but that the regulatory structure is different. Notably, all of these examples include both public and private lawmaking competitions; the rules come both from the public governments and from the private exchanges.

Some of the dynamics in private lawmaking are different from familiar U.S. federalism, however, especially because of the possibility of opting for "offshore" havens, where there may be little or no regulation. To be sure, location offshore sends its own signals about value and transparency. The crucial point here is that private lawmaking offers virtually infinite options for legal regimes, including those with different rules, those with no relevant rules, and perhaps those with no real government at all. In this way, private lawmaking is not tethered to government as federalism is in the United States. Obviously this fact could be dangerous, or liberating, or both, depending on context and ideology. On the other hand, the mere possibility of private lawmaking does not mean that anything goes. To the extent that actors want to operate in ordinary (non-offshore) jurisdictions, statebased rules of private international law can control the choice of law. ${ }^{67}$

Internet gambling provides a nice case in point. During earlier empirical research, a leading credit card bank said that the Visa and MasterCard associations were considering barring the use of their cards for Internet gambling, largely be-

65. Edward B. Rock, Coming to America?: Venture Capital, Corporate Identity and U.S. Securities Law, in Global Markets, Domestic Institutions 476, 477 (Curtis J. Milhaupt ed., 2003).

66. Heather Timmons, New York Isn't the World's Undisputed Financial Capital, N.Y. Times, Oct. 27, 2006, at C3. These foreign companies have a "fear of the United States: of litigation, of Sarbanes-Oxley, of the reach of the S.E.C., of the disclosure requirements and penalties associated with false disclosure." Id. (quoting Cole Fontayn, Bank of New York).

67. See, e.g., Gran Canaria Timeshare Cases, Bundesgerichtshof [BGH] [German Federal Court of Justice], Mar. 19, 1997, Die Deutsche Rechtsprechung auf dem Gebiet des Internationalen Privatrechts [IPRspr.] 1997, no.34. 
cause of concerns about business risk. ${ }^{68}$ These rules either did not come to fruition or did not last. This lack of private regulation led to a vertical intervention: Congress passed legislation to force the credit card banks to prevent use of their products for Internet gambling. ${ }^{69}$ (Ironically, the structure of this move highlights the governmental view that private lawmaking, had it been implemented, would have been relatively effective.) Yet there can be little doubt that there will be some who opt into other, probably "offshore" payment regimes, escaping both the U.S. credit cards and the U.S. regulation. These alternative payment systems will have their own rules. Rigidly certain rules are typically paramount in these contexts. But these rules will circumvent publicly made law. To use the Cartesian analogy for federalism, there will be no vertical check on horizontal expansion.

Perhaps one of the greatest challenges for private lawmaking in the international realm is the difficulty of instituting or finding a unifying vertical axis-a constitution to provide a structure within which private lawmaking can occur and be regulated. Currently, much of that structure will have to come from rules of private international law (e.g., rules on choice of law and enforcement of judgments). These rules can put important, practical limits on the ability of parties to import laws privately made offshore into jurisdictions that may matter more, even to the parties themselves. Whether the rules of private international law provide a sufficient system of checks or balances, however, is a large and complex question that is beyond the scope of the present paper. Nevertheless, it should be observed that some rules of structure-to enable and to check private lawmaking-will probably be necessary. These have sometimes been called "meta-rules" and point to the necessary cooperation of the state (i.e., public lawmakers) to effectuate healthy private lawmaking regimes. ${ }^{70}$ These meta-rules are similar to the idea of procedural regulation that $I$ have suggested above.

68. See Snyder, supra note 2, at 399-400, 400 n.114.

69. H.R. 4411 was incorporated into H.R. 4954, which became law when the President signed it Oct. 13, 2006. See Unlawful Internet Gambling Enforcement Act, H.R. 4411, 109th Cong. (2006); Security and Accountability for Every Port Act, Pub. L. No. 347-109, $\$ \S 801-803$, 120 Stat. 1884, 1953-62 (2006).

70. See generally Karl-Heinz Ladeur, The Role of Contracts and Networks in Public Governance: The Importance of the "Social Epistemology" of Decision-Making, 14 Ind. J. Global Legal Stud. 329 (2007) (explaining how the state administrative agencies must evolve to address the new "network society" created by private contracts and necessitated by public interest). 


\section{The Problems of Federalism, Transposed onto the Molecular Level}

Possibly the greatest challenge for federalism, and any plural lawmaking regime, is the need for coordination, uniformity, or both across a reasonably broad spectrum of commercial transactions. Evidence shows that the problem is not insurmountable, but it is formidable. The seeming strength of choice and competition that may be observed on the horizontal axis of federalism, which allows parties to choose from competing lawmaking entities, can lead to bewildering confusion. That one entity can deal with issues of electronic letters of credit, while others can try to move bills of lading (usually with a profit motive pushing the enterprise) into the electronic world, is not an unmitigated benefit. Coordination can be crucial. To continue the example, since commercial letters of credit often require a bill of lading, the lawmaking efforts need to take account of each other, and concerted effort may be required.

In fact, the need for commercial certainty and uniformity was the impetus for the current Constitution, which replaced the unsuccessful Articles of Confederation. As Daniel Webster explained, "Whatever we may think of it now, the Constitution has its immediate origin in the conviction of the necessity for this uniformity, or identity, in commercial regulations." 1 The national power-including diversity jurisdiction - provided for in the Constitution and the early implementing statutes was adopted largely to protect creditors' claims, financial markets, and private property. The timing of the constitutional drafting is worth remembering: the Framers worked from May to September 1787, just a few months after the continual armed attacks on courts to prevent foreclosures and other debt processes (generally known as Shays' Rebellion, from August 1786 to February 1787). ${ }^{72}$

Under the Constitution, and particularly its provision for federal diversity jurisdiction, ${ }^{73}$ the United States attempted to provide commercial safety and uniformity backed by national power. Many thought that the development of a federal common law of commerce would be helpful in this unifying effort, and the Constitution, as interpreted by the Supreme Court, attempted to achieve this unifor-

71. Daniel Webster, quoted in Issacharoff \& Sharkey, supra note 15, at 1399, and Alfred B. Teton, The Story of Swift v. Tyson, 35 ILL. L. Rev. 519,538 n.107 (1940).

72. Ron Chernow, Alexander Hamilton 225 (2004); Issacharoff \& Sharkey, supra note 15, at 1399-1400.

73. U.S. Const. art. III, $\$ 2$. 
mity during the long regime of Swift $v$. Tyson, ${ }^{74}$ which allowed the federal courts to make common law even in diversity cases (i.e., cases that did not involve any federal law but that were subject to federal jurisdiction simply because the litigants were citizens of different states). The experiment proved unsuccessful, however, as its unexpected result was a multiplication of legal rules and counter-rules as state and federal courts announced common law rules along separate and sometimes contradictory lines. ${ }^{75}$ This multiplicity was, in the end, unsustainable, and the Supreme Court finally ended it in Erie R.R. v. Tompkins in $1938,{ }^{76}$ primarily on grounds of federalism, and more particularly, state powers.

This historical experience suggests a limit on the number or variety of lawmakers, at least in the commercial realm (and likely even more generally as more and more becomes commoditized). ${ }^{7}$ This experience also suggests that at least some markets may require a small number of dominant lawmakers, or perhaps an exclusive regime. Plural legal regimes, after all, impose costs. Inconsistent or simply multiplicitous rules raise costs on enterprises that seek to do business across several jurisdictions, and such enterprises necessarily incur added information costs just to determine what laws apply when and where. Litigation and transaction costs can increase as more auxiliary disputes arise, both in contract negotiation and in dispute resolution, over choice of law and forum. Nor do the rules themselves come free; drafting the rules, and the concomitant study, thought, and lobbying, cannot be ignored. Further, greater ranges of choices, and greater possibilities for remaking or revisiting those legal choices, increase costs associated with instability. The further important problem of externalities is also unavoidable and will be discussed shortly. ${ }^{78}$ These costs have to be taken into account when evaluating private lawmaking and assessing the benefits, especially along the axis of horizontal federalism, discussed in the preceding section.

Empirical study so far is inconclusive as to whether the market for laws will produce an efficient balance of diversity and uniformity. One hypothesis suggests

74. 41 U.S. 1 (1842). See generally Henry J. Friendly, The Historic Basis of Diversity Jurisdiction, 41 Harv. L. Rev. 483 (1928) (discussing how courts initially dealt with diversity jurisdiction and the creation of federal common law).

75. See Issacharoff \& Sharkey, supra note 15, at 1398-1407.

76. 304 U.S. 64 (1938).

77. For discussions illustrating this point, see Michele Goodwin, Black Markets: The Supply and Demand of Body Parts (2006); Rethinking Commodification: Cases and Readings in Law and Culture (Martha M. Ertman \& Joan C. Williams eds., 2005).

78. See, e.g., Larry E. Ribstein \& Bruce H. Kobayashi, An Economic Analysis of Uniform State Laws, 25 J. Legal STud. 131, 138-40 (1996) (explaining most of the costs more fully). 
that uniform regimes will attract adherents and achieve greater uniformity only when uniformity is efficient (i.e., when the benefits of uniformity outweigh its costs). Some evidence supports this hypothesis. On the other hand, there is also evidence that suggests that private, uniform regimes are overproduced, and that while some wither for lack of adherents, others gain adherents-presumably because of some kind of irrational faith in uniformity - and produce inefficient uniformity. After all, pluralism may be better, largely for the very reasons given above in defense of federalism..$^{79}$

That molecular federalism lacks the coordination that inheres in constitutional, governmental federalism nevertheless presents certain opportunities. Coordination does not come easily, even when it may be desirable or even efficient, and private lawmaking efforts can potentially break the statist logjam. Private codifications may achieve a level of adherence and uniformity that is not possible when international coordination of governments proves infeasible. Hence, private or quasi-private efforts at unification can, if they achieve enough adherents, move toward an arguably necessary uniformity that has been hampered by state (in)action. The UCP and perhaps the Incoterms have had immense success and have achieved startling uniformity without significant governmental assistance. ${ }^{80}$ Grander efforts have so far had less success, although the story is not over, and supranational government has itself attempted to harness the power of private lawmaking through the encouragement of private or quasi-private efforts toward uniform rules. Examples include the Unidroit Principles of International Commercial Contracts and the Principles of European Contract Law. ${ }^{81}$ Nevertheless, if a dominant private regime does emerge, it is subject to challenge on legitimacy grounds, as exit is not a real possibility. If no dominant regime emerges, then the cost of multiplicity will remain. This whipsaw effect is a significant flaw for private lawmaking.

Another problem is that some private lawmaking structures are likely to lead to problems of externalities. The most likely are those exemplified by the interbank agreements authorized by UCC Article 4, discussed above. There is no reason, absent government regulation, why many such interbank agreements would

79. For further assessment of the costs of uniformity (and thus the benefits of pluralism), see id. at 140-41.

80. See Snyder, supra note 2, at 389-95.

81. Michael Jonchim Bonell, An International Restatement of Contract Law: The UNIDROIT Principles of International Commercial Contracts (3d ed. 2005) (incorporating the UNIDROIT Principles 2004); Principles of European Contract Law: Parts I and II (Ole Lando \& Hugh Beale eds., rev. ed. 2000); Principles of European Contract Law: Part III (Ole Lando et al. eds., 2003). 
not seek to externalize bank costs onto customers who do not consent but who are nevertheless bound. This dynamic will also occur in any situation where private lawmaking is imposed without consent and without competition. Some rentseeking can even be found in the UCP, where money-center banks impose their favored rules on other banks. ${ }^{82}$ To the extent that many lawmaking processes only include some of the affected parties, ${ }^{83}$ negative externalities are likely.

Finally, some private lawmaking regimes also seem likely to produce a market for lemons. To simplify (and perhaps oversimplify): where consumers are rationally uninformed as to some terms, because finding out about them is literally not worth the time, those terms can escape competition, and lemons are a possible result. ${ }^{84}$ Producers, whether of cars or of rules, can evade competition on anything consumers do not care to find out about. Credit card rules would seem likely to lead to a race to the bottom for terms other than interest rates and the like, and many would probably point to the arbitration term as a case in point. Although there is likely to be disagreement normatively, again largely on ideological grounds, one economic point is worth making: in a market for lemons, one cannot say that consumers are choosing to pay less money for a lesser (or riskier) product. ${ }^{85}$ The informational asymmetry deprives consumers, including consumers of privately made laws, of any real choice.

\section{Conclusion}

As the United States has shifted from its eighteenth-century origins, the operation and conception of federalism has changed. This transformation has inevitably been shaped by the market revolutions and machinations of the nineteenth and early twentieth centuries, the prescriptions of the New Deal in the 1930s, and

82. See Snyder, supra note 2, at 393.

83. See id. at $434-35$.

84. See generally Akerlof, supra note 44. There is a necessary qualification. In some circumstances, competition may alter the premise, and consumers may become informed. For instance, if a competitor discovers that another seller's term would be unattractive to consumers, then that competitor may inform consumers, e.g., through advertising. See Frank H. Easterbrook, Contract and Copyright, 42 Hous. L. Rev. 953, 968-70 \& nn. 32-33 (2005). On the other hand, a competitor who discovers such a term may use the same term itself and profit by not disclosing the information.

85. See, e.g., Carnival Cruise Lines v. Shute, 499 U.S. 585, 594 (1991) (upholding a forum selection clause, reasoning in part that the lower litigation costs are being passed along to consumers, and implying that consumers might well choose this tradeoff to get lower fares). Note also that only some of the savings will be passed along to consumers, assuming (as is likely the case) that demand is not completely inflexible. 
the rights-based outlook inherited from nineteenth-century laissez faire and later transferred to criminal procedure and human rights. Instead of concentrating on the division of power between national and state governments, current policy refocuses on a division of power between private actors (including large organizations) on the one hand and governments on the other, whether on the national, subnational, or supranational levels. What the redactors of the French Civil Code saw as lawmaking power between two atomistic private parties has evolved in the crucible of national and international trade into larger combinations of multinational firms and associations, and more complex, compound molecular structures that make and enforce their own rules.

This political structure allows real opportunities for private lawmaking, here envisioned as molecular federalism. Private lawmaking can realize many of the benefits of federalism but with greater depth and breadth. It also has the qualitative advantage of being extraterritorial. At the same time, molecular federalism suffers many of the same problems as governmental federalism. The theoretical assessment of molecular federalism is thus mixed. So too is the practical side, as should be expected. Examining individual efforts at private lawmaking shows that once a sturdy private lawmaking regime surfaces, the spontaneous free space for competitive lawmaking efforts often disappears or at least contracts, as seems to be the case with the UCP and letters of credit. But there are counterexamples, such as in the sovereign debt market, even if rule changes are slow and careful.

Domestically, the problems of molecular federalism are susceptible to an easier solution. At the very least, the national government can act as a public check on private lawmaking and thus balance undue expansion on the horizontal axis. Because of the transnational and extraterritorial dimension of private lawmaking, however, some problems will likely prove intractable. Especially to the extent that activities are mobile, particularly if they can move offshore, private lawmaking regimes can evade the kind of public interest balance represented by the vertical axis of federalism. This phenomenon is profoundly troubling in the context of activities like human commoditization and offshore payments and suggests that some strategy or strategies-whether conceived as constitution, meta-rules, or something else-must be implemented to include the public interest as part of an international polity that includes private lawmaking.

The epigraph from Wechsler is not a bad measure for trying to assess the necessarily mixed benefits and costs of private lawmaking and molecular federalism. That society is "far flung," and growing outward, seems undeniable. The other questions are harder. Is society "free," and more particularly, does molecular fed- 
eralism help make it freer? In a theoretical sense, molecular federalism helps. Private lawmaking, and the ever-present potential for new and alternative lawmaking regimes to arise, allows both organized spaces for ordered relationships and free spaces for libertarian experimentation. This conception of federalism helps achieve some of Professor Teubner's goals. To paraphrase and generalize his response to Lawrence Lessig, "Politically, the point would not be ... to combat ... corporatism, but to stabilise and institutionally guarantee the spontaneous/organised difference as such. The constitution ... would distinguish between spontaneous public sectors ... and highly formalised organised sectors. ${ }^{\text {"86 }}$ The organized spaces allow a banding together to resist peril and advance welfare, whether through governmental or private organization. Thus corporatism, private and public, occurs in this organized space; it is the realm of the state, the business corporation, the labor union, the political party, and the club. The preservation of free, unorganized space allows those who are dissatisfied with current organizations to exit and to form new combinations, encouraging a growing diversity and a healthy ferment, a dynamic of experiment and learning, irritation and response, presentiation and relationship-building.

86. Teubner, supra note 5 , at 28 . I recognize that the concluding paragraph may invert some of Professor Teubner's ideas about the organized and the free spaces and the location of rights. Nevertheless (and perhaps surprisingly), I believe that my conception of the dialectical relationshipthe communication - between the two spaces is similar to his. Systems theory posits communications and erases individuals. LuнmanN, supra note 4, at 467 . This emphasis is consonant with the metaphor of the molecule, which exists only as a compound and only because of the bonds between the atoms. Both contracting, and on a larger scale, lawmaking, require this bond, relation, or communication. To some degree, my ideas must depart from the systems theorists', however. Some rights, to my mind, are inextricably part of the individual, or at least a party; I cannot conceive of rights as floating free of individuals or other parties. In my conception, there are two kinds of rights: those that inhere in individual actors, which are invariable, and those provided by institutions, which are variable. Parties who exist within the organized sphere enjoy the rights provided by organized institutions. If these actors prefer, however, they can exit the organized sphere and enter the open space, where they still retain their invariable and inviolate individual rights, including the right to recombine with others, to form new combinations (and thus institutions), and to return to the organized space. This movement or communication between the organized sphere and the free sphere provides an important check on the institutions already within the organized sphere. In other words, the ability to exit the organized sphere and recombine with others in the free space (governed only by "fundamental rights" and the "constitutional law of the market") allows the potential for infinite recombinations and thus infinite alternatives to the institutions (whether state, company, or union) that already inhabit the organized space. Cf. Teubner, supra note 5, at 24. 